\section{Peptic Ulcer}

\section{Disease as}

\section{a Common Cause} of Bleeding in

\section{Patients with}

\section{Coronavirus}

\section{Disease 2019}

Federica Melazzini, MD, PhD',

Marco Vincenzo Lenti, MD¹,

Aurelio Mauro, MD ${ }^{1}$, Federico De Grazia, MD ${ }^{1}$ and Antonio Di Sabatino, $\mathrm{MD}^{1}$

Am J Gastroenterol 2020;00:1-2. https://doi.org/ 10.14309/ajg.0000000000000710

The clinical spectrum of severe acute respiratory syndrome coronavirus 2 (SARS$\mathrm{CoV}-2$ ) infection is wide, ranging from an asymptomatic infection to a severe viral pneumonia which may be fatal (1-3). Preliminary evidence from studies conducted during the coronavirus disease 2019 (COVID-19) pandemic supports the notion that patients with COVID-19 may have an increased susceptibility to develop venous thromboembolism, and this is why thromboprophylaxis is warranted (4). However, the risk of bleeding in patients with COVID-19 still remains unclear and could be potentially high in elderly patients with multimorbidity. A case of hemorrhagic colitis related to COVID-19 has been recently reported (5), although nothing is known regarding the risk of upper gastrointestinal (GI) bleeding in these patients.

We report a series of 5 consecutive patients admitted to our internal medicine unit due to COVID-19 pneumonia. All of them suffered from at least a chronic disease, being essential hypertension present in 4 cases. None of them had a history of peptic ulcer disease, nor of Helicobacter pylori infection. The diagnosis of COVID19 was based on a nasopharyngeal swab positive for SARS-CoV-2 by reverse transcriptase polymerase chain reaction assay.
All patients presented with fever, dry cough, and dyspnea and were treated with nonmechanical ventilation. On admission, all patients received low-molecular-weight heparin. After a median time of 9 days, all patients developed severe anemia and clinical manifestations of upper GI bleeding, i.e., melena and hypotension. Fluids and blood transfusions were given as per clinical need, and except for one case having poor clinical conditions who subsequently died, all patients underwent upper GI endoscopy. Table 1 summarizes the most relevant patients' demographic, clinical, laboratory, and endoscopic features and Figure 1 shows 2 peptic ulcers, specifically one with active bleeding (right side).

Notably, gastric and/or duodenal ulcer was the most common finding, and in 2 cases, multiple ulcers were found. One case of rebleeding occurred within 48 hours, and selective arterial embolization was performed. During the time of bleeding patients' enrollment, a total number of 96 patients with COVID-19 were admitted to our ward. Hence, a crude prevalence of upper GI bleeding of $5.2 \%$ was found. This number is relatively high, considering the internal

Table 1. Demographic, clinical, laboratory, and endoscopic features of patients with COVID-19 with GI bleeding

\begin{tabular}{|c|c|c|c|c|c|c|c|c|c|c|c|c|c|}
\hline $\mathrm{Pt}$ & Age & Sex & $\begin{array}{l}\text { Signs of } \\
\text { GI } \\
\text { bleeding }\end{array}$ & $\begin{array}{l}\text { Days from } \\
\text { admission to } \\
\text { bleeding }\end{array}$ & $\begin{array}{c}\text { Anticoagulant } \\
\text { therapy }\end{array}$ & $\begin{array}{l}\mathrm{Hb} \\
(\mathrm{g} / \mathrm{dL})\end{array}$ & $\begin{array}{l}\text { Endoscopic } \\
\text { findings }\end{array}$ & $\begin{array}{l}\text { Number } \\
\text { of ulcers }\end{array}$ & Localization & Size & $\begin{array}{c}\text { Endoscopic } \\
\text { therapy }\end{array}$ & Rebleeding & Outcome \\
\hline 1 & 81 & M & $\begin{array}{c}\text { Tarry } \\
\text { stool, } \\
\text { anemia }\end{array}$ & 10 & $\begin{array}{l}\text { Enoxaparin } \\
6000 \text { Ul/bid }\end{array}$ & 6.9 & $\begin{array}{c}\text { Forrest III } \\
\text { ulcers }\end{array}$ & 3 & $\begin{array}{l}2 \text { antrum } \\
1 \text { bulb }\end{array}$ & $6-8 \mathrm{~mm}$ & None & No & Discharged \\
\hline 2 & 78 & M & $\begin{array}{c}\text { Tarry } \\
\text { stool, } \\
\text { anemia }\end{array}$ & 19 & $\begin{array}{l}\text { Enoxaparin } \\
4000 \text { UI/die }\end{array}$ & 3.9 & $\begin{array}{c}\text { Forrest III } \\
\text { ulcer }\end{array}$ & 1 & Antrum & $15 \mathrm{~mm}$ & None & No & Discharged \\
\hline 3 & 58 & $M$ & $\begin{array}{l}\text { Tarry } \\
\text { stool, } \\
\text { anemia }\end{array}$ & 4 & $\begin{array}{l}\text { Enoxaparin } \\
6000 \text { Ul/die }\end{array}$ & 6.8 & $\begin{array}{l}\text { Forrest Ib } \\
\text { ulcer } \\
\text { Forrest III } \\
\text { ulcers }\end{array}$ & $\begin{array}{r}1 \\
5-10\end{array}$ & $\begin{array}{l}\text { Bulb } \\
\text { Antrum }\end{array}$ & $\begin{array}{l}15 \mathrm{~mm} \\
3-6 \mathrm{~mm}\end{array}$ & $\begin{array}{l}\text { Adrenaline } \\
\text { and clips }\end{array}$ & $Y_{e s}{ }^{a}$ & Discharged \\
\hline 4 & 77 & $\mathrm{~F}$ & $\begin{array}{c}\text { Tarry } \\
\text { stool, } \\
\text { anemia }\end{array}$ & 12 & $\begin{array}{l}\text { Enoxaparin } \\
6000 \text { Ul/bid }\end{array}$ & 8.6 & $\begin{array}{l}\text { Erythematous } \\
\text { gastropathy }\end{array}$ & I & $\begin{array}{c}\text { Entire } \\
\text { stomach }\end{array}$ & I & None & No & Discharged \\
\hline 5 & 71 & M & $\begin{array}{c}\text { Tarry } \\
\text { stool, } \\
\text { anemia }\end{array}$ & 2 & $\begin{array}{l}\text { Enoxaparin } \\
4000 \text { UI/die }\end{array}$ & 5.8 & $\begin{array}{c}\text { Upper Gl } \\
\text { endoscopy } \\
\text { not performed }\end{array}$ & I & I & I & I & I & Dead \\
\hline
\end{tabular}



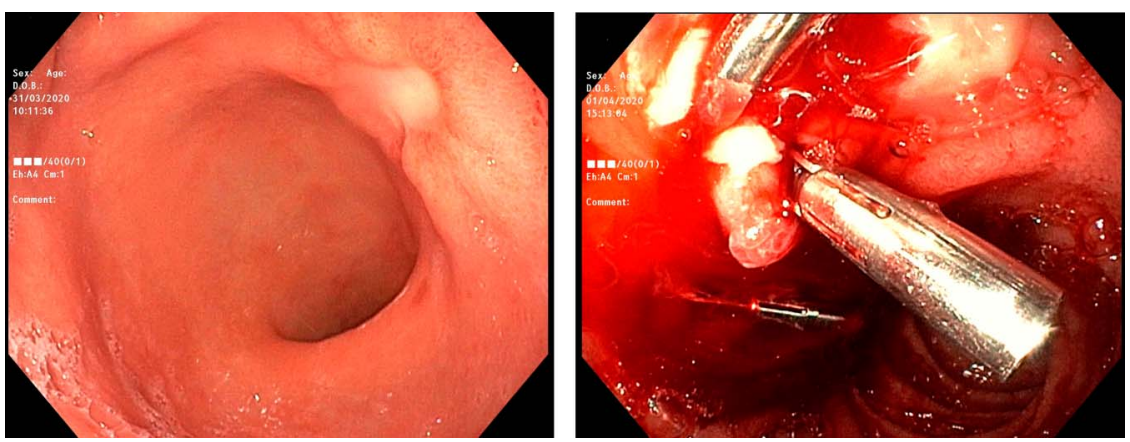

Figure 1. High-resolution, white light, endoscopic images showing a Forrest III ulcer of the posterior wall of the antrum without a need for endoscopic treatment (left side; patient 2) and active bleeding from a Forrest Ib ulcer of the anterior wall of the duodenal bulb treated with adrenaline injection $(6 \mathrm{~mL}$ of diluted adrenaline 1/10,000) and clips (total of 3 metallic clips, Instinct Cook; right side; patient 3).

medicine setting. Of note, none of the 5 patients presented with other risk factors for bleeding than thromboprophylaxis, and none of them received therapies that could interact with platelet function or coagulation factor synthesis. In addition, platelet count was normal, and secondary hemostasis parameters were unremarkable.

The clinical spectrum of COVID-19 is yet to be completely understood. The pathogenesis of peptic ulcer disease might be explained by different mechanisms, including stress resulting from the acute illness, direct gastric epithelial damage caused by SARS-CoV-2, or active mucosal inflammation sustained by the cytokine storm. If thromboprophylaxis remains a key point in the management of patients with COVID-19, the relatively high risk of GI bleeding should alert the clinician in routinely checking for its occurrence by monitoring laboratory parameters and hemodynamic stability. However, given the current effective endoscopic and radiologic tools in managing an active GI bleeding, thromboprophylaxis should not be discouraged.

\section{CONFLICTS OF INTEREST}

Guarantor of the article: Antonio Di Sabatino, MD.

Specific author contributions: All authors participated in the drafting of the paper, made critical revision to the manuscript for important intellectual content, and provided approval of the final submitted version.
Financial support: None to report. Potential competing interests: None to report.

Informed consent: All patients provided written informed consent for the publication of their anonymized data in the form of a case series.

\section{REFERENCES}

1. Guan WJ, Ni ZY, Hu Y, et al. Clinical characteristics of Coronavirus disease 2019 in China. N Engl J Med 2020;382:1708-20.

2. Chen N, Zhou M, Dong X, et al.

Epidemiological and clinical characteristics of 99 cases of 2019 novel coronavirus pneumonia in Wuhan, China: A descriptive study. Lancet 2020;395:507-13.

3. Li LQ, Huang T, Wang YQ, et al. 2019 novel coronavirus patients' clinical characteristics, discharge rate, and fatality rate of metaanalysis. J Med Virol 2020. [Epub ahead of print March 12, 2020.]

4. Marietta M, Ageno W, Artoni A, et al. COVID19 and haemostasis: A position paper from Italian society on thrombosis and Haemostasis (SISET). Blood Transfus 2020. DOI 10.2450/ 2020.0083-20.

5. Carvalho A, Alqusairi R, Adams A, et al. SARS$\mathrm{CoV}-2$ gastrointestinal infection causing hemorrhagic colitis: Implications for detection and transmission of COVID-19 disease. Am J Gastroenterol 2020. [Epub ahead of print April 17, 2020.]

${ }^{1}$ Department of Internal Medicine, San Matteo Hospital Foundation, University of Pavia, Pavia, Italy. Correspondence: Antonio Di Sabatino, MD. E-mail: a.disabatino@smatteo.pv.it. 